\title{
Character Education Values in Revised Edition of the Indonesian Language Learning Curriculum for Year 10
}

\author{
Tri Santoso ${ }^{1,2, *}$, Sujianto ${ }^{3}$, Dodi Afianto ${ }^{2}$, Duwi Saputro ${ }^{4}$, Atiqa Sabardila ${ }^{1}$, \\ Endang Fauziati ${ }^{1}$, Markhamah ${ }^{1}$ \\ ${ }^{1}$ Faculty of Education and Teaching, Universitas Muhammadiyah Surakarta, Indonesia \\ ${ }^{2}$ Doctorate Student of Islamic Education Management, Institut Agama Islam Negeri Surakarta, Indonesia \\ ${ }^{3}$ Faculty of Social Sciences and Political Sciences, Universitas Riau, Indonesia \\ ${ }^{4}$ Universitas Muhammadiyah Surakarta, Indonesia
}

Received November 10, 2019; Revised December 24, 2019; Accepted December 30, 2019

Copyright $\subseteq 2020$ by authors, all rights reserved. Authors agree that this article remains permanently open access under the terms of the Creative Commons Attribution License 4.0 International License

\begin{abstract}
Character building is an important component of 2013 Curriculum learning using textbooks as a learning source. This study aims to describe character values within the 2014 and 2017 revised editions of the 2013 Curriculum-based Indonesian Language Textbook for Year 10. The source of data for this research is the 2013 Curriculum Indonesian Language Textbook (BTBI) published by the Ministry of Education and Culture (Kemendikbud). Data in this study assume the forms of words, phrases, or sentences that indicate character values, collected by observation and note-taking and analyzed with a referential identity method. The 2014 and 2017 editions of BTBI carry the same character values, namely religiousness, nationalism, independence, gotong royong, and integrity. Differences in the character value content of both textbooks lie in the sub-values of each identified character value. According to the uncovered character sub-values, the dominant character in the 2014 edition of BTBI is independence. The 2017 edition contains three equivalent character values: religiousness, nationalism, and independence. Principles of Wasatiyyat Islam reflected in BTBI for Year 10 are values of tawassut (taking the middle way), tawazun (balance between the world and the hereafter), i’tidal (straightness and uprightness), tasamuh (tolerance), musawah (egalitarianism), shura (consultation), islah (reform), aulawiyah (prioritizing), tatawwur wa ibtikar (dynamism and innovation), and tahaddur (being civilized). These values represent the courteous, peaceful and gentle nature of the Indonesian nation.
\end{abstract}

Keywords Learning, Education, Character Education, Language Learning

\section{Introduction}

Education continues to evolve along the transition from the 20th to the 21st century. This change is marked by global educational imperatives, such as Education For All (EFA), Education for Sustainable Development (ESD), Millennium Development Goals (MDGs), and World Literacy for Empowerment (Gülmezoglu \& Lawrie, 2015; Jacob, 2017; Hendarman et al., 2018). In addition, discovery and innovation in education make it not only serve to develop the intellectual life of the nation's generations but also contribute in strengthening their character.

Education does not only play its role as a means for the transfer of knowledge, but also as a medium for shaping the character, attitude, behavior and leadership of the youth (Rokhman et al., 2014; Ülger, 2014; Kim, 2015). Change in all fields between the 20th and 21st century is paradigmatic, as at the end of the 20th century Indonesia underwent novelties in the state, governance, social and cultural systems. Regarding education, for instance, 2015 was the last year for the policies of Education For All, Millennium Development Goals, and the national education agenda.

In accordance with this situation, the government of Indonesia has conducted reforms by placing character as a fundamental matter. The government has sought to strengthen the character of learners through the Character Education Reinforcement (PPK) program as featured in the Regulation of the Minister of Education and Culture of the Republic of Indonesia (Permendikbud) Number 20 Year 2018 on Character Education Reinforcement in formal educational units. In line with this, the government has implemented the latest curriculum which is the 2013 Curriculum. One of the characteristics of learning in the 2013 Curriculum is the duty to guide learners to understand their potentials, interests, and talents to develop their 
careers in higher education or society (Kemendikbud, 2017). Thereby, school plays an important role in strengthening learners' character by means of curricular and extracurricular activities.

PPK is carried out with a class-based approach, involving school culture and the society. According to Permendikbud No. 20 Year 2018, a class-based approach integrates character values into a thematic learning process or subjects designated in the curriculum. The learning process involves various components such as textbooks. The government facilitates this by publishing textbooks through the Ministry of Education and Culture (Kemendikbud, 2018), which have been revised on several occasions including in 2014 and 2017. As a component of learning, textbooks play their own part in character education (Barry et al., 2013; Fahmy et al., 2015).

Psychology observers particularly in bibliotherapy presume that interesting reading material inspires children to act out contents of the story and apply them in their behavior (Joling et al., 2011; Eliasa \& Iswanti, 2014; Montgomery \& Mauders, 2015; Gerlach \& Subramanian, 2016; Agustina, 2017). Based on this view, a pilot character building campaign for learners has been devised using attractive texts by the government through a character literacy movement via textbooks in every subject on different education levels (Ferdiawan \& Putra, 2013; Fahmy et al., 2015; Nopilda \& Kristiawan, 2018; Wiedarti et al., 2018).

Building learners' characters is one of the key aspects of education. Characters are embodied in norm standards and value systems implemented in varied forms of individual qualities through human activities. This corroborates Basri (2012:13), John Dewey (in Nugroho, 2013:19), and Mei-Ju, Chen-Hsin, and Pin-Chen (2014) in that education is used as platform in building the nation's civilization, and as a reconstructive and progressive effort for the Indonesian people in the future.

Words, phrases, clauses, or sentences featured in the Indonesian Language Textbook (henceforth abbreviated as BTBI) contain not only character education values but also messages of gentleness and peace. These lessons align with the practical principles of Wasatiyyat (moderate) Islam formulated by the Indonesian Ulema Council in its National Conference (Munas) IX in Surabaya, 24-27 August 2015 (Tempo, 2015), and the concept of Wasatiyyat Islam proposed by the Indonesian President's Special Envoy for Interfaith Dialog and Civilization Affairs during the High Level Consultation of World Muslim Scholars on Wasatiyyat Islam in Bogor, 1-3 May 2018. Wasatiyyat Islam is regarded as the teaching of Islam as rahmatan lil-alamin, or a mercy to the worlds. Its principles comprise tawassut (taking the middle way), tawazun (balance between the world and the hereafter), i'tidal (righteousness), tasamuh (tolerance), musawah (egalitarianism), shura (consultation), islah (reform), aulawiyah (prioritizing), tatawwur wa ibtikar (dynamism and innovation), and tahaddur (being civilized).

Character education reinforcement by textbook starts from early education stages. Wulandari and Sinaga (2016) disclosed that short story texts in the BTBI for Grade VII bear character values as an iteration of PPK. Values introduced in those short stories include piousness, honesty, tolerance, discipline, hard work, creativity, independence, democracy, curiosity, respectful achievements, hospitality/sociability, peace-loving, environmental care, social care, and responsibility.

Research by Abdullah et al. (2016) found that role playing in learning history is highly effective in instilling character education values in children, and Barry (2013) concludes from ten tested books that books can be used for the same purpose. Meanwhile, Markhamah et al. (2017) suggest that the Quran indicates positive and negative characterizations in relation to the names of numbers.

In a study by Rahayu (2018), the implementation of 5 S culture is proved effective in improving the characters of the school community. If applied consistently, it would increase school performance and the school may become reference for the application of character education. Research by Relin et al. (2018) also shows that folktales are relevant teaching materials for elementary school students because such tales introduce values of honesty, compassion, respect, and courtesy.

Internalization of character values by education is one concrete step in the transformation of education in Indonesia. Character values in education are expected to complement intellectuality built within every learner's self. The character value content in textbooks becomes essential as their role cannot be separated from the learning process in the 2013 Curriculum.

\section{Research Methodology}

This study is qualitative descriptive and aims to describe the character content in the 2014 and 2017 revised editions of the Indonesian Language Textbook for Year 10 based on the 2013 Curriculum. The data sources in this research are the Self and Academic Expression Indonesian Language Textbook (2014) and Indonesian Language Textbook (2017). The data consist of words, phrases, clauses, sentences, and paragraphs which contain elements of character education for learners.

Data were collected by an observation method attending to language use (Mahsun, 2017). The term attending in this method is not limited to listening to oral language use but also covers reading written language. This method was followed up by note-taking.

The data were then analyzed with an identity method since the determinants of the analysis comes from outside language. Sudaryanto (2015) explains that an identity method is utilized in linguistic analysis whose determinants lie beyond linguistic elements and are no part 
of the pertinent language (langue). The identity method used was referential identity in which the determinants are the referents in the data. The foregoing analysis technique corresponds to content analysis, which is required in order to draw conclusions from the available data (Fraenkel et al., 2011; Lune \& Berg, 2016; Bengtsson, 2016).

\section{Results and Discussion}

Education is one of the environments used to shape the character of learners in a structured way through the curriculum. Concurrently, character education reinforcement can be carried out within the family and society. Character education in Indonesia stems from the Indonesian nation's culture acquired from the contexts of family, education, and neighborhood (Siwi, 2016). Table 1 below presents findings on character education in general in the 2014 and 2017 revised editions of BTBI for year 10.

Table 1. Findings on Character Education Values

\begin{tabular}{|c|l|l|}
\hline No & Classification & \multicolumn{1}{c|}{ Character } \\
\hline \multirow{1}{*}{1} & $\begin{array}{l}2014 \text { Revised } \\
\text { Edition of } \\
\text { BTBI Year 10 } \\
\text { faith, vigilance, fondness of reading, } \\
\text { fondness of writing, sincerity, democracy, } \\
\text { trustworthiness, cooperation, } \\
\text { communication, creativity, independence, } \\
\text { respect to others' opinions, deliberation for } \\
\text { consensus, obedience, environmental care, } \\
\text { social justice, self-belief, spirit of unity, } \\
\text { curiosity, duty awareness, animal care, } \\
\text { school spirit, spirit of entrepreneurship, and } \\
\text { fondness of saving }\end{array}$ \\
\hline \multirow{2}{*}{2} & $\begin{array}{l}\text { Edition } \\
\text { BTBI Year 10 }\end{array}$ & $\begin{array}{l}\text { faith and piety, trust in Allah, gratitude, } \\
\text { sincerity, supplication to Allah, honesty, } \\
\text { communication, self-belief, democracy, } \\
\text { obedience, fondness of reading, hard work, } \\
\text { cooperation, leading by example, } \\
\text { creativity, independence, appreciation of } \\
\text { ancestral culture, environmental care, } \\
\text { social care, curiosity, modesty, national } \\
\text { spirit, responsibility, and mutual assistance }\end{array}$ \\
\hline
\end{tabular}

The main values in character education reinforcement (PPK) cited in Hendarman et al. (2018) comprise religiousness, nationalism, independence, gotong royong, and integrity. These main values are delineated in sub-values featured in BTBI revised editions of 2014 and 2017.

\subsection{Character Values Language Textbook Year 10 Revised Edition of 2014}

The 2014 revision of BTBI Year 10 incorporates all the primary values in character education reinforcement. Character values uncovered in this book amount to 24 and spread across the five key values. The dominant primary value in this edition of BTBI Year 10 is independence, which encompasses 14 character sub-values, followed by nationalism (five sub-values), religiousness (four sub-values), gotong royong (four sub-values), and integrity (one sub-value). The character sub-values found for each main value can be seen in Table 2 .

Table 2. Character sub-values in 2014 revised edition of BTBI Year 10

\begin{tabular}{|l|l|}
\hline Main Character Value & Character Sub-value \\
\hline Religiousness & $\begin{array}{l}\text { Faith and piety, trust in Allah, gratitude, } \\
\text { sincerity, supplication to Allah, } \\
\text { self-belief }\end{array}$ \\
\hline Nationalism & $\begin{array}{l}\text { Democracy, environmental care, } \\
\text { appreciation of ancestral culture, } \\
\text { obedience, national spirit, modesty }\end{array}$ \\
\hline Independence & $\begin{array}{l}\text { Communication, fondness of reading, } \\
\text { hard work, creativity, independence, } \\
\text { curiosity, self-belief }\end{array}$ \\
\hline Gotong royong & \begin{tabular}{l} 
Cooperation, social care \\
\hline Integrity
\end{tabular} \\
\hline
\end{tabular}

\subsection{Character Values in Language Textbook Year 10 Revised Edition of 2017}

The 2017 revised edition of BTBI Year 10 hails 25 character sub-values distributed into the five main character values, namely religiousness (six sub-values), nationalism (six sub-values), independence (seven sub-values), gotong royong (two sub-values), and integrity (four sub-values). It can be observed that the BTBI Year 10 revision of 2017 has fairly balanced values of religiousness, nationalism, and independence. The character sub-values disclosed in the 2017 edition of BTBI Year 10 are depicted in Table 3.

Table 3. Character sub-values in 2017 revised edition of BTBI Year 10

\begin{tabular}{|l|l|}
\hline Main Character Value & Character Sub-value \\
\hline Religiousness & Faith, sincerity, animal care, self-belief \\
\hline Nationalism & $\begin{array}{l}\text { Democracy, spirit of unity, duty } \\
\text { awareness, environmental care, } \\
\text { obedience }\end{array}$ \\
\hline Independence & $\begin{array}{l}\text { Independence, vigilance, fondness of } \\
\text { reading, fondness of writing, } \\
\text { communication, creativity, curiosity, } \\
\text { spirit, school, spirit of entrepreneurship, } \\
\text { fondness of saving others' opinions, cooperation, }\end{array}$ \\
\hline Gotong royong & $\begin{array}{l}\text { Respect to othens } \\
\text { social justice, deliberation for consensus }\end{array}$ \\
\hline Integrity & \begin{tabular}{l} 
Trustworthiness \\
\hline
\end{tabular}
\end{tabular}

\subsection{Character Education Reinforcement in Indonesian Language Textbook Year 10}

Character education reinforcement differs between the 2014 and 2017 revisions of BTBI Year 10. The predominant character value in the 2014 edition is independence, whilst the 2017 version possesses three balanced characters which are religiousness, nationalism, and independence. Comparisons of character values in both books are shown in Table 4. 
Table 4. Distribution of Character Values in BTBI Year 10

\begin{tabular}{|l|c|c|}
\hline Main Character Value & F (2014 Revision) & F (2017 Revision) \\
\hline Religiousness & 6 & 4 \\
\hline Nationalism & 6 & 5 \\
\hline Independence & 7 & 11 \\
\hline Gotong royong & 2 & 4 \\
\hline Integrity & 4 & 1 \\
\hline
\end{tabular}

\subsubsection{Religiousness}

The character value of religiousness is manifested by behavior in daily life. Such manifestation of religious values includes good conduct (akhlak al-karîmah), such as being hospitable, fair, wise, patient, grateful, polite, caring, responsive, responsible, independent, fond of cleanliness, peace-loving, etc., all of which represent the qualities of the Messenger of Allah (Siswanto, 2013).

Habituation in all activities done by learners includes learning at school. Habituation of character values in learning requires integration of learning components. The realization of such integration is the composition of teaching material in the shape of modules to support the learning process at school in order to nurture the religious character of students (Nurjanah, 2018).

The religious character contained in the 2014 and 2017 editions of BTBI for Year 10 seeks to fortify learners' faith and submission to God and urge them to always plead to Him. The next character of religiousness conveyed in BTBI is sincerity by highlighting exemplary figures in text who lend a hand sincerely. The sub-value of animal care is demonstrated with affection and caring for animals, while self-belief is portrayed to boost the self-confidence of learners.

\subsubsection{Nationalism}

Indonesia is a country boasting diverse tribes, cultures and languages. This diversity establishes Indonesia as a plural state with high potential for conflict. Such potential can be suppressed by strengthening the character of nationalism, as its prime purpose is to inspire patriotism. Fatmawati (2012) asserts that to minimize potential for conflict and prevent recurrences, the root of the problem needs to be treated by reinforcing patriotism and nationalism through multicultural teachings in formal education.

The goals of learning character value content in both revised editions are: firstly, to introduce responsible freedom of speech which does not transgress norms; secondly, to lift the spirit to live together and cooperate in diversity; thirdly, to teach to not damage the environment and to maintain its sustainability; and lastly, to educate learners to perform their duties as good citizens and respect plural cultures.

\subsubsection{Independence}

The character value of independence denotes the attitude and behavior of not relying on others and using one's whole energy, thought and time to realize hopes and dreams (Hendarman et al., 2018). The 2014 edition of BTBI Year 10 positions independence as a dominant character value, while the 2017 revision sets independence as the character with the most sub-characters at seven.

The aims of independence in BTBI for Year 10 involve educating students to adapt and be accustomed to their surroundings. Learners are directed to be creative and produce novelties through innovation. Furthermore, they are guided to have high curiosity which is a typical trait of learners. The independence character in BTBI Year 10 is situated in biography texts.

\subsubsection{Gotong Royong}

Gotong royong is a character value inspired by the people of Indonesia. In general, the principle of gotong royong incorporates substantial values of the belief in God, familial spirit, deliberation and consensus, justice, and tolerance (humanity) which serve as a basis for the views of life or philosophy of the Indonesian nation (Utomo, 2018).

One of the objectives of the gotong royong character in BTBI Year 10 is to educate learners to live well within a multicultural society. Learners are taught to care, to be able to cooperate in the society, and to put forward consultation and consensus to solve problems.

\subsubsection{Integrity}

The integrity character value reflects the condition of matching one's words with deeds. Integrity can also be expressed by a strong moral commitment in performing a task. According to Hendarman et al. (2018), the character of integrity covers responsible attitudes as a citizen and active participation in social life through consistency between truthful words and actions.

The reinforcement of integrity by BTBI Year 10 aims in part to implant honesty into learners so that they become trustworthy individual. The sub-character of responsibility in BTBI for Year 10 is expected to shape the personality of students who are able to lead by example in fulfilling their duties toward themselves, the society and the environment.

\subsection{Principles of Wasatiyyat Islam in Indonesian Language Textbook Year 10 Revised Editions of 2014 and 2017}

Wasatiyyat signifies moderation and balance (i'tidal) in faith, morality and character (al-Qudsy et al., 2015). The character in question is the way one treats others, either in a sociopolitical or governmental system. The opposite of wasatiyyat is extremism (tatarruf), which from an Islamic perspective applies to anyone who exceeds the boundaries and provisions of the Sharia. Tatarruf also relates to those who cross the line of moderation or the majority view (ra'y al-jamaah). The ummatan wasatan and Wasatiyyat Islam concepts are intellectual responses against the tendency of escalating extremism among Muslims. 
Table 5. Wasatiyyat Islam principles in character education values in BTBI Year 10

\begin{tabular}{|l|l|l|}
\hline Wasatiyyat Islam Principle & Character education values (BTBI Revised Edition 2014) & $\begin{array}{l}\text { Character education values (BTBI } \\
\text { Revised Edition 2017) }\end{array}$ \\
\hline Tawassut & faith and piety, trust in Allah, supplication to Allah & trust in Allah \\
\hline Tawazun & sincerity & gratitude, sincerity \\
\hline I'tidal & spirit of unity & national spirit \\
\hline Tasamuh & respect to others' opinions & appreciation of ancestral culture \\
\hline Musawah & social justice & social care, mutual assistance \\
\hline Shura & democracy, cooperation, deliberation for consensus & democracy, cooperation \\
\hline Islah & communication, independence, self-belief & $\begin{array}{l}\text { communication, } \\
\text { independence }\end{array}$ \\
\hline Aulawiyah & vigilance, fondness of saving & hard work \\
\hline Tatawwur wa Ibtikar & $\begin{array}{l}\text { spirit of entrepreneurship, fondness of reading, fondness of } \\
\text { writing, spirit school, creativity, curiosity }\end{array}$ & $\begin{array}{l}\text { fondness of reading, creativity, } \\
\text { curiosity }\end{array}$ \\
\hline Tahaddur & trustworthiness, duty awareness, environmental care, obedience & $\begin{array}{l}\text { honesty, responsibility, obedience, } \\
\text { leading by example, environmental } \\
\text { care, modesty }\end{array}$ \\
\hline
\end{tabular}

Wasatiyyat Islam values and principles are also displayed in the character education values embedded in BTBI. These principles ini can be implemented to reduce social conflict and disintegration of the plurality and multiculturalism of the Indonesian people. Table 5 presents Wasatiyyat Islam principles identified within character education values in BTBI Year 10.

Tawassut literally means taking the middle way, while as a term tawassut is defined as proportionate understanding and practice of religion and restriction of religious teachings not delivered by Prophet Muhammad. The Wasatiyyat Islam principles present in BTBI for Year 10 are faith and piety, trust in Allah, and supplication to Allah. These three attributes are considered an embodiment of taking the middle way in religious terms, not the extreme right or left, and putting religion at its rightful place.

The principle of tawazun in BTBI Year 10 consists of gratitude and sincerity. Sincerity is the gracious acceptance of all gifts from Allah, whereas gratitude is one's expression of thankfulness to Him. Both indications of tawazun represents balance between the world and the hereafter. After work is done, the awaited outcome shall be accepted with sincerity and gratitude. Tawazun results from proportional comprehension and practice of religion between worldly life and the afterlife, upholding principles, and the capacity to distinguish between difference and deviance.

I'tidal as a Wasatiyyat Islam principle in BTBI Year 10 is marked by the spirit of unity and nationalism. This quality firmly devotes itself to forging unity and building a superior, more advanced and more self-sustained civilization toward the establishment of Indonesia as baldatun tayyibatun wa rabbun ghafur. The i'tidal principle puts everything in its proper place, assumes rights and fulfils obligations proportionately.

The principle of tasamuh in BTBI Year 10 is denoted by respect to others' opinions and appreciation of ancestral culture, both of which epitomize high tolerance. The multicultural state of Indonesia is blessed with diverse tribes, religions, races, ethnicities, and cultures, to the extent that a lack of reciprocal respect would lead to disintegration of the nation. It is therefore necessary to keenly introduce the value of tasamuh to every citizen since school age. Tasamuh is known as a sense of acknowledgement and respect toward dissimilarities, both in religious aspects and in other aspects of life.

The following principle is musawah, found in BTBI Year 10 in the character education values of social justice, social care, and mutual assistance. Musawah is the indiscriminative stance toward others despite differences in religion, faith, origin or tradition. Social justice, social care, and mutual assistance are actual manifestations of the musawah principle and the fourth principle of Pancasila as the national ideology of Indonesia.

Shura as a Wasatiyyat Islam principle in BTBI Year 10 is demarcated by the characters of democracy, cooperation, and deliberation for consensus. Democracy is the character that offers an equal opportunity to every person to voice opinions, whilst cooperation signifies working together to achieve a common goal. The shura (consultation) principle is to tackle any issue by cooperation and deliberation to reach a consensus, where benefit for the people is championed above all else.

The principle of islah or often referred to as reforms in BTBI Year 10 is exemplified by communication, independence, and self-belief. The creation of novelties necessitates good communication, independent changes, and belief in oneself. The islah principle prioritizes reforms to attain a better situation that accommodates change and progress centered on public benefit (maslahah 'ammah) while holding on the principle of al-muhafazah 'ala al-qadimi al-salih (maintaining the good old) wa al-akhdhu 
bi al-jadidi al-aslah (and taking the better new).

The subsequent character is aulawiyah or prioritizing, which is marked in BTBI Year 10 by the characters of vigilance, hard work, and fondness of saving. Vigilance is the character of a learner who carefully sets priorities of activities by weighing in the positive and negative effects. Hard work is putting maximum effort by selecting which task needs precedence and which can be temporarily set aside. Fondness of saving denotes the strategy of sparing money for future priority needs. It is necessary to teach these characters to learners from early age to prepare them for their future life. Aulawiyah as a Wasatiyyat Islam principle indicates the ability to identify which matters are more urgent and thus come first.

Tatawwur wa ibtikar is a dynamic and innovative character, implicated in BTBI Year 10 by spirit of entrepreneurship, fondness of reading and writing, school spirit, creativity, and curiosity. These characters ought to be developed in the mindset and value set of learners so as to produce quality graduates full of spirit and energy who swiftly respond and adapt to challenges and opportunities with innovation or novelty. This principle is always open to change in accordance with current developments and the creation of new amenities for the benefit and advancement of mankind.

The last principle is tahaddur or a civilized state, which is depicted in BTBI Year 10 by honesty, responsibility, leading by example, environmental care, modesty, trustworthiness, duty awareness, environmental care, and obedience. These are superior characters of the national civilization of Indonesia which should be emulated by other states and nations in this era of morality crisis today.

\subsection{Wasatiyyat Islam as Reflection of the Civilized Nation of Indonesia}

Wasatiyyat Islam is a central religious teaching which in many respects has not met its full potential in real-life application, either locally, nationally, or globally. Wasatiyyat Islam involves dimensions of vastness, nobility and beauty. This teaching brings peace, order and harmony. It is the responsibility of Islam adherents to implement the ten aforementioned principles of Wasatiyyat Islam in concrete actions, with the purpose of erasing the negative perception toward the people of Islam particularly that of Indonesia whose small part is said to exhibit violence, terrorism and other extremist acts.

Wasatiyyat Islam can be proposed as solution for the civilization of humankind which has endured various forms of crises, ranging from food and energy to the environment. Such crises conspicuously arise from a faulty anthropocentric global system far from spirituality, ethics and mores. Therefore, the time has come for the Islam nation to rise and improve itself and to exercise the true teachings of Islam, so that Islam is conceded as a solver of civilization issues instead of being seen as part nor creator of such problems.

The world of education requires strong commitment to invite all of its constituents to campaign and raise the cosmopolitan and universal values of Wasatiyyat Islam. In general education founded on Islam, several groups have tried to propose the concept of wasatiyyat Indonesian Islam into an idea scheme that is contextualized with new international norms. They attempt to interpret the humanitarian values of an open Wasatiyyat Islam perspective, recognize human rights and pluralism, and accommodate the idea of compatibility between Islam and democracy, citizenship, tolerance, and gender equality. Education in Indonesia also influences the development of Wasatiyyat Islam characters.

Education in Indonesia with its varied forms of institutions provides a good model that accommodates, collaborates with and adapts to local cultural values. Teaching materials bearing the characters and principles of Wasatiyyat Islam are a vital element of lessons at school, and are difficult to find in other countries. This distinctive education in Indonesia contributes to Islamic education which teaches Wasatiyyat Islam with peace and warmth.

\section{Conclusions}

The 2014 revised edition of BTBI for Year 10 features five primary values in the character education reinforcement program, namely religiousness (faith, sincerity, animal care, self-belief), nationalism (democracy, spirit of unity, duty awareness, environmental care, obedience), independence (self-reliance, vigilance, fondness of reading, fondness of writing, communication, creativity, curiosity, school spirit, spirit of entrepreneurship, fondness of saving), gotong royong (respect to others' opinions, cooperation, social justice, deliberation for consensus), and integrity (trustworthiness).

The 2017 revision of the same book also introduces the five key values but with the sub-values of faith and piety, trust in Allah, gratitude, sincerity, supplication to Allah, and self-belief (religiousness), democracy, environmental care, appreciation of ancestral culture, obedience, national spirit, and modesty (nationalism), communication, fondness of reading, hard work, creativity, independence, curiosity, and self-belief (independence), cooperation and social care (gotong royong), and honesty, leading by example, mutual assistance, and responsibility (integrity). The main differences between the two editions lie in the dominant value and the uncovered sub-values.

The principles of Wasatiyyat Islam represented in BTBI for Year 10 are the values of tawassut (taking the middle way), tawazun (balance between the world and the hereafter), i'tidal (righteousness), tasamuh (tolerance), musawah (egalitarianism), shura (consultation), islah (reform), aulawiyah (prioritizing), tatawwur wa ibtikar (dynamism and innovation), and tahaddur (being civilized). 
These values reflect the character of the courteous, peaceful and gentle nation of Indonesia.

\section{REFERENCES}

[1] Agustina, S. (2017). Biblioterapi untuk Pengasuhan: Membangun Karakter Anak dengan Kisah. Bandung: Noura Publishing.

[2] Abdullah, A., Zulkifli, M., Gunawan, F., Zulaeha, Z., Ratnaningsih, S., Achmad, A. D., \& Chik, W. (2016). "Instilling Values Character Education through Playing Role Model in Learning History". Journal of Human Relations, 23(2), 24-33.

[3] al-Qudsy, S.H.S.I., Basir, S. A., Azmi, I. A. G., Ahmad, S. N. S., \& Nayan, I. (2015). Diversiti Konsep Wasatiyyah: Aplikasi Menerusi Inovasi dalam Perkhidmatan Awam. Jurnal Psikologi \& Kaunseling Perkhidmatan Awam Malaysia, 10, 183-207.

[4] Barry, A. L., Rice, S., \& McDuffie-Dipman, M. (2013). Books with Potential for Character Educational and Literacy-rich Social Studies Classroom: A Reasearch Study: The Journal of Social Studies Research, 37, 47-61.

[5] Bengtsson, M. (2016). How to Plan and Perform a Qualitative Study Using Content Analysis. NursingPlus Open, 2, 8-14.

[6] Eliasa, E. I., \& Iswanti, S. (2014). Bibliotherapy with the Career Topic to Increase the Student's Career Motivation of Guidance and Counseling. Procedia-Social and Behavioral Sciences, 114, 434-438.

[7] Fahmy, R., Bachtiar, N., Rahim, R., \& Malik, M. (2015). Measuring Student Perceptions to Personal Characters Building in Education: an Indonesian Case in Implementing New Curriculum in High School. Procedia-Social and Behavioral Sciences, 211, 851-858.

[8] Fatmawati, L., Pratiwi, R. D., \& Erviana, V. Y. (2012). Pengembangan Modul Pendidikan Multikultural Berbasis Karakter Cinta Tanah Air dan Nasionalis pada Pembelajaran Tematik. Scholaria: Jurnal Pendidikan dan Kebudayaan, 8(1), 80-92.

[9] Ferdiawan, E., \& Putra, W. E. (2013). Esq Education for Children Character Building Based on Phylosophy of Javaness in Indonesia. Procedia-Social and Behavioral Sciences, 106, 1096-1102.

[10] Gerlach, H., \& Subramanian, A. (2016). Qualitative Analysis of Bibliotherapy as A Tool for Adults Who Stutter and Graduate Students. Journal of Fluency Disorders, 47, $1-12$.

[11] Gülmezoglu, A. M., \& Lawrie, T. A. (2015). Impact of Training on Emergency Resuscitation Skills: Impact on Millennium Development Goals (MDGs) 4 and 5. Best Practice \& Research Clinical Obstetrics \& Gynaecology, 29(8), 1119-1125.

[12] Hendarman, H., Saryono, D., Supriyono, Kamdi, W., Sunaryo, Latipun, Winarsunu, T., Chamisijatin, L., et al. (2018). Konsep dan Pedoman Penguatan Pendidikan Karakter Tingkat Sekolah Dasar dan Sekolah Menengah
Pertama. Jakarta: Kemendikbud.

[13] Jacob, A. (2017). Mind the Gap: Analyzing the Impact of Data Gap in Millennium Development Goals'(MDGs) Indicators on the Progress Toward MDGs. World Development, 93, 260-278.

[14] Joling, K. J., Van Hout, H. P., van't Veer-Tazelaar, P. J., van der Horst, H. E., Cuijpers, P., van de Ven, P. M., \& van Marwijk, H. W. (2011). How Effective is Bibliotherapy for Very Old Adults With Subthreshold Depression? A Randomized Controlled Trial. The American Journal of Geriatric Psychiatry, 19(3), 256-265.

[15] Kantor Urusan Khusus Presiden Republik Indonesia Bidang Kerja Sama antar Agama dan Peradaban. (2018). Wasatiyyat Islam: Konsepsi dan Implementasinya. Jakarta: Setpres.

[16] Kemendikbud. (2017). Panduan Implementasi Kecakapan Abad 21 Kurikulum 2013 di Sekolah Menengah Atas. Jakarta: Kemendikbud.

[17] Kemendikbud. (2018). Permendikbud Nomor 20 Tahun 2018 Tentang Penguatan Pendidikan Karakter pada Satuan Pendidikan Formal. Jakarta: Kemendikbud.

[18] Kim, D. (2015). A Study on the Class of Education that Builds Students' Character through Films-Classes at The University of Liberal Arts. Procedia-Social and Behavioral Sciences, 174, 1529-1533.

[19] Lune, H., \& Berg, B. L. (2016). Qualitative Research Methods for the Social Sciences. Harlow: Pearson Higher Ed.

[20] Mahsun. (2017). Metode Penelitian Bahasa. Depok: Rajawali Pers.

[21] Markhamah, M., Ngalim, A., Sabardila, A., Yafi, M. A., \& Reistanti, A. P. (2017). A Character Investigation through The Referential Naming on Al-Qur'an. The 1st International Conference on Language, Literature and Teaching.

[22] Mei-Ju, C., Chen-Hsin, Y., \& Pin-Chen, H. (2014). The Beauty of Character Education on Preschool Children's Parent-Child Relationship. Procedia-Social and Behavioral Sciences, 143, 527-533.

[23] Montgomery, P., \& Maunders, K. (2015). The Effectiveness of Creative Bibliotherapy for Internalizing, Externalizing, and Prosocial Behaviors in Children: a Systematic Review. Children and Youth Services Review, 55, 37-47.

[24] Nopilda, L., \& Kristiawan, M. (2018). Gerakan Literasi Sekolah Berbasis Pembelajaran Multiliterasi Sebuah Paradigma Pendidikan Abad Ke-21. JMKSP (Jurnal Manajemen, Kepemimpinan, dan Supervisi Pendidikan), 3(2).

[25] Nurjanah, Fenti, D. (2018). Pengembangan Bahan Ajar Tematik Terintegrasi Nilai-nilai Islam dan Sains untuk Meningkatkan Karakter Religius Siswa. Pendas:Jurnal Ilmiah Pendidikan Dasar, III(20), 178-181.

[26] Rahayu, S. W. (2018). "Implementation of Character Education through Culture 5S (Senyum, Sapa, Salam, Sopan dan Santun) At State Junior High School 2 Ngawi (Smpn 2 Ngawi) East Java Indonesia". International Research Based Education Journal, 1(2), 130-135. 
[27] Relin, R., Rasna, I. W., \& Binawati, W. S. (2018b). "Values Implied in the Wratisasana Palm Manuscripts as Guideline of Politeness in Language of the Character Education: A Study of Theo-Ethno Pedagogy". Journal of Language Teaching and Research, 9(1), 90-96.

[28] Rokhman, F. \& Syaifudin, A. (2014). Character Education for Golden Generation 2045 (National Character Building for Indonesian Golden Years). Procedia - Social and Behavioral Sciences, 141, 1161-1165.

[29] Siswanto. (2013). Pendidikan Karakter Berbasis Nilai-nilai Religius. Tadris:Jurnal Pendidikan Islam, 8(1), 91-107.

[30] Siwi, Dini Pamungkas, Endah Peniati, Y. U. A. (2016). Analisis Muatan Pendidikan Karakter dalam Buku Teks Pelajaran IPA Kurikulum 2013 pada Materi Biologi Kelas VII SMP. Unnes Journal of Biology Education, 5(2), 207213. Retrieved from

[31] Tempo. 2015. "Munas MUI IX Tawarkan Konsep Islam Moderat". https://nasional.tempo.co/read/695010/munas-m ui-ix-tawarkan-konsep-islam-moderat. diakses pada 27/8/2 019.

[32] Ülger, M., Yiğittir, S., \& Ercan, O. (2014). Secondary School Teachers' Beliefs on Character Education Competency. Procedia-Social and Behavioral Sciences, 131, 442-449.

[33] Utomo, E. P. (2018). Internalisasi Nilai Karakter Gotong Royong dalam Pembelajaran IPS untuk Membangun Modal Sosial. 3(2), 95-102.

[34] Wiedarti, P., Laksono, K., dan Retnaningsih, P. (2018). Desain Induk Gerakan Literasi Sekolah. Jakarta: Kemendikbud.

[35] Wulandari, A., \& Sinaga, A. (2016). Nilai-nilai Pendidikan Karakter dalam Cerpen dalam Buku Teks Bahasa Indonesia SMP Kelas VII Terbitan Erlangga Tahun 2013. Pena, 6(1), 20-34. 